included the structure, origin and functions of the following cell constituents: metagranules, multivesicular bodies, lysosomes, yolk platelets, cortical granules, ribosomes, endoplasmic reticulum and, finally, mitochondria. The schedule included formal presentations by the lecturers followed by free discussion from the participants, the discussions being under the general guidance of Prof. Runnström. Some topics were supplemented by demonstrations and practical laboratory work. The general aim of the course was to attempt to bring together the many different experimental techniques applied to colhular constituents in order to elucidate problems of developmental biology and hence enable embryological research to benefit from the newer conceptions of these cellular elements. Moreover, the content of the mature presentations included many important aspects of nucleo-cytoplasmic relationships, such as information transfer and realization at the level of the egg cell and early embryo. It is to be hoped that such cross-fertilization of disciplines involving development will be continued in the future and that new ideas for research in embryology will ensue from this first venture.

\section{Virus Disease of a Fungus}

Some of the disorders affecting mushroom crops can be corrected by altering the conditions of cultivation, and others are known to be caused by pathogenic fungi or bacteria that have been identified. There are, however, a number of disorders the causes of which have for many years been unknown. It has now been shown that some, and possibly most, of these are different manifestations of virus infection. An article by M. Hollings, Doreen G. Gandy and Dr. F. T. Last of the Glasshouse Crops Research Institute, published in a recent number of Endeavour, describes the isolation of these viruses, and the criteria by which they were identified and shown to cause disease the first known case of a virus infecting a fungus (22, No. 87; September, 1963).

\section{Advances in Medical Treatment}

A sPecral number of The Practitioner deals with advances in medical treatment $(191$, No. 1144; October 1963). While there is nothing sensational to report, progress is being achieved and is largely the result of co-crdination and improvement in methods of treatment. The keynote of the number is best described as one of caution. Potent drugs must be used with a full appreciation of their hazards. New surgical techniques must only bo used provided there is good evidence that the patient will benefit. This last point is well brought out in Prof. Haagensen's review dealing with "Advances in the Treatmont of Cancer". In some ways the most important advances in treatment have been achieved in the field of psychiatry where the introduction of the so-called tranquillizers has resulted in a marked amelioration in the lot of the mentally ill. Even here, however, a note of caution is required. These drugs may have done much to improve the outlook for the individual patient, but they have raised almost as many problems as they have solved. There is still a long way to go before the processes which lead to such obvious psychoses as schizophrenia can be explained. The overall picture, however, is one of sober optimism.

\section{Animal Reproduction and Artificial Insemination}

THE fifth international congress on "Animal Reproduction and Artificial Insemination" will be held in Trento during September 6-13. During the congress the following three prizes will be offered for original experimental work: the Prof. Antonio Pirocchi Prize, for work concerning an aspect of the problem of animal reproduction or artificial insemination within the framework of the development of livestock production; the Prof. Carlo del Bo Prize, for work concerning the technique of the collection, insemination by inoculation, the dilution and the preservation of the spermatic material of any species of animal excluding the horse; the Giulio Gallici Prize, for work concerning the artificial reproduction or insemina. tion of horses. Further information can be obtained from the General Secretary of the Congress, Via Monte Ortigara 35, Milan.

\section{Fellowships at Churchill College, Cambridge}

Churchill Colleat, Cambridge, is offering junior research fellowships in arts, mathematics, science, or engineering. Applieants must be under the age of thirty on July 1, 1964, and not have spent more than four year's in research work. The fellowships are for an initial period of three years and are of the value of $£ 700$ a year. An accommodation allowance of $£ 200$ and a children's allowance of $£ 100$ for each child is also paid to Fellows not resident in College. The College is also offering a Gulbenkian fellowship which is open to graduates of any university other than those in the United Kingdom who wish to carry out advanced work, and is of the same value as the junior research fellowships. The tenure is normally for one year but may be extended. Applieants must be under the age of thirty on July 1, 1964, and not have spent more than four years in research work. Details of methods of application, which must be made by February 1, can be obtained from the Senior Tutor, Churchill College. Cambridge.

\section{Announcements}

DR. R. Spence, deputy director of the Atomic Energy Research Establishment, Harwell, has been appointed director of the Establishment in succession to Dr. F. A. Vick, who has been appointed a full-time member of the Atomic Energy Authority.

Dr. Ugo Fano and Dr. Richard C. Mockler have been awarded the 1963 Samuel Wesley Stratton Awards of the National Bureau of Standards. Dr. Fano is an assistant director and senior Research Fellow and Dr. Mockler is chief of the Atomic Frequency and Time Interval Standards Section at the National Bureau of Standards (Boulder). The two recipients will each receive a bronze plaque and an honorarium of 1,500 dollars. Dr. Fano receives his award for his "profound influence on the field of atomic physies through his personal scientific creativity and through his stimulation of many others at NBS". Dr. Mockler receives his award for "his outstanding achievements in leading the NBS atomic frequency and timo standards program".

The Autumn Foray of the British Mycological Society will be held in Belfast during September 3-10. Further information can be obtained from $\mathrm{Mr}$. J. C. Taylor, Department of Mycology and Plant Pathology, Quoen's University, Elmwood Avenue, Belfast 9.

Tre twenty-ninth annual general meeting of the Scottish Section of the Society for Analytical Chemistry will be held in Glasgow on January 24. Further information can be obtained from the Society for Analytical Chemistry, 14 Belgrave Square, London, S.W.1.

A symeosium on "Surface Activity and the Microbial Cell", arranged under the auspices of the Society of Chemical Industry, will be held in London during September 24-25. Further information can be obtained from the Honorary Secretary, Symposium on Surface Activity and the Microbial Cell, 14 Belgrave Square, London, S.W.1.

AN ordinary meeting of the Midlands Section of the Society for Analytical Chemistry will be held in the University of Birmingham on February 5. The programme will include a brains trust on "High Purity Chemicals". Further information can be obtained from the Socioty for Analytical Chemistry, 14 Belgrave Square London, S.W.1. 